\title{
PENERAPAN METODE TGT (TEAM GAME TOURNAMENT) MENINGKATKAN HASIL BELAJAR BAHASA INGGRIS PADA SISWA KELAS VIII DI SMP NEGERI 1 BANDAR BARU
}

\author{
Nasruddin \\ SMP Negeri 1 Bandar baru Pidie Jaya \\ nasruddinsmp@gmail.com
}

\begin{abstract}
Abstrak
Penelitian ini bertujuan untuk mengetahui peningkatan motivasi belajar yang pada akhirnya akan meningkatkan hasil belajar siswa pada pembelajaran Bahasa Inggris Kelas VIII dengan penerapan TGT (Team Game Tournament) pada materi Unit self-test di SMP Negeri 1 Bandar Baru, semester II tahun ajaran 2015/2016. Jenis penelitian ini termasuk penelitian action research. Subyek penelitian ini adalah siswa Kelas VIII di SMP Negeri 1 Bandar Baru. Hasil penelitian ini menunjukkan: Melalui hasil penelitian tindakan kelas pada SMP Negeri 1 Bandar Baru terjadi peningkatan motivasi belajar yaitu pada siklus I rata-rata sebesar 68,10 sedangkan pada siklus II sebesar 80,00. Sebelum dilakukan pembelajaran dengan Metode TGT (Team Game Tournament) nilai siswa adalah 60,71. Pada siklus I hasil evaluasi siswa pada mata Pelajaran Bahasa Inggris Materi Unit self-test mendapatkan nilai rata-rata 70,00, sedangkan pada siklus II mendapatkan nilai rata-rata 80,00. Dari penelitian tersebut terjadi peningkatan ketuntasan belajar sebesar pada siklus I sebesar 33\% dan pada siklus II sebesar 95\%. Dengan demikian, dapat disimpulkan bahwa dilaksanakannya penelitian tindakan kelas melalui Metode TGT (Team Game Tournament) terhadap pembelajaran Bahasa Inggris pada materi Unit selftestdapat meningkatkan motivasi belajar yang dengan sendirinya dapat meningkatkan hasil belajar pada siswa Kelas VIII SMP Negeri 1 Bandar Baru .
\end{abstract}

Kata Kunci : Metode TGT (Team Game Tournament), Hasil Belajar

\begin{abstract}
This study aims to determine the increase in learning motivation which in turn will improve student learning outcomes in learning Class VIII English with the application of TGT (Team Game Tournament) on the self-test unit material at Bandar Baru 1 Junior High School, second semester 2015/2016 academic year.This type of research includes action research. The subjects of this study were Class VIII students at SMP Negeri 1 Bandar Baru. The results of this study indicate: Through the results of classroom action research at SMP Negeri 1 Bandar Baru there was an increase in learning motivation, namely in the first cycle the average was 68.10 while in the second cycle was 80.00. Before learning with the TGT (Team Game Tournament) Method, the student score is 60.71. In the first cycle, the results of student evaluations in the eyes of English Language Subjects The self-test unit gets an average score of 70.00, while in the second cycle it gets an average score of 80.00 . From the study there was an increase in learning completeness as much as in the first cycle of $33 \%$ and in the second cycle by $95 \%$. Thus, it can be concluded that the implementation of classroom action research through the TGT (Team Game Tournament) Method of learning English in the material The self-test unit can increase learning motivation which by itself can improve learning outcomes for Class VIII students at SMP Negeri 1 Bandar Baru.
\end{abstract}

Keywords: TGT Method (Game Tournament Team), Learning Outcomes 


\section{LATAR BELAKANG}

Penguasaankemampuan

Bahasa Inggris (language skill) merupakan sebuah syarat mutlak yang harus dimiliki di era komunikasi dan globalisasi saat ini. Pembelajaran Bahasa Inggris (Language Learning) di jenjang SMP/MTs merupakan materi pokok sebagai bagian dari fungsi pengembangan diri siswa dalam bidang Ilmu Pengetahuan, teknologi dan seni yangdiharapkan setelah menamatkan studi, Mereka mampu tumbuh dan berkembang menjadi individu yang cerdas, terampil dan berkepribadian sebagai bekal hidup di masa mendatang.

Penguasan materi pelajaran Bahasa Inggris dalam jenjang SMP/MTs meliputi empat keterampilan berbahasa, yaitu: menyimak, berbicara, membaca dan menulis. Semua itu didukung oleh unsurunsur bahasa lainnya, yaitu: Kosa Kata, Tata Bahasa dan Pronunciation sesuai dengan tema sebagai alat pencapai tujuan. Dari ke empat keterampilan berbahasa di atas, Writing (menulis) merupakan salah satu kemampuan berbahasa yang dirasa sering menjadi masalah bagi siswa dalam proses pembelajaran Bahasa Inggris. Hal tersebut sangat menarik untuk diteliti mengingat kemampuan menulis (writing ability) sangatlah dipengaruhi oleh penguasaan kosa kata, struktur bahasa dan kemampuan siswa dalam merangkai kata menjadi sebuah teks yang berterima. Perbedaan secara grammatical antara bahasa Inggris sebagai bahasa asing dan bahasa Indonesia sebagai bahasa utama merupakan masalah yang sering timbul pada saat belajar menulis.

Data yang diperoleh peneliti menyatakan bahwa hasil Belajar Bahasa Inggris siswa rendah, berdasarkan ketuntasannya siswa belum dapat dikatakan tuntas. Siswa dikatakan tuntas apabila $\geq$ (KKM) 70.

Tolok ukur keberhasilan pembelajaran pada umumnya adalah prestasi belajar. Prestasi belajar Bahasa Inggris untuk beberapa kompetensi dasar umumnya menunjukkan nilai yang rendah. Hal ini standar kompetensi dan kompetensi dasar Bahasa Inggris kelas memang sarat akan materi, di samping cakupannya luas dan perlu hafalan. Jika dilihat dari hasil ulangan harian sebagian besar masih di bawah kriteria ketuntasan minimal (KKM) yaitu sebesar $33 \%$ hanya 7 siswa yang telah memenuhi standar ketuntasan minimal. Dengan rata -rata kelas sebesar 60,71.

Dari uraian di atas dapat diasumsikan bahwa mata pelajaran pengetahuan sosial mempunyai nilai yang strategis dan penting dalam mempersiapkan sumber daya manusia yang unggul, handal, dan bermoral. Hal yang menjadi hambatan selama ini dalam pembelajaran bahasa Inggris adalah disebabkankurang dikemasnya dengan metode yang menarik, menantang dan menyenangkan. Para guru sering kali menyampaikan materi bahasa Inggris apa adanya (konvensional), sehingga pembelajaran bahasa Inggris cenderung membosankan dan kurang

Pembelajaran kooperatif adalah salah satu bentuk pembelajaran yang berdasarkan faham konstruktivis. Pembelajaran kooperatif merupakan strategi belajar dengan sejumlah siswa sebagai anggota kelompok kecil yang tingkat kemampuannya berbeda. Dalam menyelesaikan tugas kelompoknya, setiap siswa anggota kelompok harus saling bekerja sama dan saling membantu untuk memahami materi pelajaran. Dalam pembelajaran kooperatif, belajar dikatakan belum selesai jika salah satu teman dalam kelompok belum menguasai bahan pelajaran.

Berdasarkan latar belakang di atas maka penulis tertarik untuk mengadakan penelitian dengan judul "PenerapanMetode TGT (Team Game Tournament) Meningkatkan Hasil Belajar Bahasa Inggris pada Siswa Kelas VIII di SMP Negeri 1 Bandar Baru".

\section{KERANGKA TEORITIS \\ Pengertian Pembelajaran model teams games tournament (TGT)}


Pembelajaran kooperatif model TGT adalah salah satu tipe model pembelajaran kooperatif yang mudah diterapkan, melibatkan seluruh siswa tanpa harus ada perbedaan status. Tipe ini melibatkan peran siswa sebagai tutor sebaya, mengandung unsur bermain yang bisa menggairahkan semangat belajar dan mengandung penguatan. Aktivitas belajar dengan permainan yang dirancang dalam pembelajaran model kooperatif tipe TGT memungkinkan siswa dapat belajar dengan suasana yang menyenangkan disamping menumbuhkan tanggung jawab, kejujuran, kerja sama,persaingan sehat dan keterlibatan siswa dalam belajar.

Menurut slavin (2010, 166:167) terdapat lima komponen utama dalam pelaksanaan model pembelajaran kooperatif tipe TGT yaitu :

1) Presentasi kelas atau pengamatan

langsung

Presentasi kelas digunakan guru untuk memperkenalkan materi pelajaran dengan pengajaran langsung atau diskusi ataupun presentasi audiovisual. Guru membagi kelompok siswa serta menyebutkan konsepkonsep yang harus dipelajari, memberikan cerita singkat untuk pendahuluan mengenai materi yang akan diajarkan dalam kehidupan sehari-hari. Perbedaan presentasi kelas dengan pembelajaran biasa adalah presentasi kelas difokuskan pada unit TGT, hal ini mengandung arti bahwa siswa harus memberikan perhatian penuh pada saat presentasi kelas karena akan sangat membantu mereka menjawab soal-soal pada saat kompetisi dalam permainan berlangsung.

2) Belajar Kelompok

Tim terdiri dari empat atau lima siswa yang mewakili seluruh bagian dari kelas dalam hal kinerja akademik, jenis kelamin, ras dan etnisitas. Fungsi utama dari tim ini adalah memastikan bahwa semua anggota tim benar-benar belajar danlebih khususnya lagi adalah untukmempersiapkan anggotanya dalam kompetisi yang akan dilakukan dalam sebuah permainan. Setelah guru menyampaikan materinya, tim berkumpul untuk mempelajari lembar kegiatan atau materi lainnya. Pembelajaran tim sering melibatkan pembahasan permasalahan bersama, membandingkan jawaban, dan mengoreksi tiap kesalahan pemahaman apabila anggota tim ada yang membuat kesalahan. Pada model pembelajaran Teams Games Tournament ini poin penting yang perlu ditekankan adalah membuat anggota tim melakukan yang terbaik untuk membantu tiap anggotanya.

3) Game (permainan)

Permainan disusun untuk menguji pengetahuan yang dicapai siswa dan biasanya disusun dalam bentuk pertanyaanpertanyaan yang relevan dengan materi yang disampaikan pada saat presentasi kelas dan latihan lainnya. Permainan dalam pembelajaran kooperatif tipe Teams Games Tournament dapat berupa permainan yang mudah dikenal.

4) Turnamen

Turnamen adalah sebuah struktur dimana permainan berlangsung. Biasanya berlangsung pada akhir minggu atau ahir unit, setelah guru memberikan presentasi di kelas dan tim telah melaksanakan kerja kelompok dengan lembar kegiatan. Dalam turnamen masing-masing siswa mewakili tim yang berbeda. Kompetisi yang seimbang ini memungkinkan para siswa dari semua tingkat kinerja sebelumnya berkontribusi secara maksimal terhadap skor tim mereka, jika mereka melakukan yang terbaik. Setelah turnamen selesai maka dilakukan penilaian.

5) Team recognize

Guru kemudian mengumumkan kelompok yang menang, masing-masing tim akan mendapatkan sertifikat penghargaan apabila rata-rata skor memenuhi kriteria yang ditentukan. Tim akan mendapatkan julukan"Super Team" jika rata-rata skor 45 atau lebih, "Great Team" apabila rata-rata skor mencapai 40-45 dan "Good Team" apabila rata-rata skor 30-40 Langkahlangkah dalam pelaksanaan model pembelajaran kooperatif tipe teams games tournament adalah 
1) Buatlah kelompok siswa secara heterogen dengan jumlah anggota 4 hingga 5 orang kemudian berikan informasi pokok materi dan mekanisme kegiatan.

2) Siapkan meja turnamen secukupnya, misalkan 5 meja dan untuk tiap meja ditempati 4 siswa yang memiliki kemampuan yang setara, meja turnamen satu diisi oleh siswa dengan kemampuan tertinggi dari tiap kelompok dan seterusnya sampai meja ke $\mathrm{x}$ di tempati oleh siswa yang memiliki kemampuan terendah dari tiap kelompok. Penentuan tiap siswa yang duduk pada meja tertentu sesui dengan kesepakatan kelompok.

3) Pelaksanaan turnamen setiap siswa mengambil satu kartu pertanyaan dan satu siswa lagi memegang kartu jawaban, siswa yang memegang kartu soal berhak menjawab, apabila jawabannya salah maka pertanyaan akan dilempar pada siswa selanjutnya. Apabila jawabannya benar dan sesuai dengan kartu jawaban maka kartu tersebut dapat disimpan oleh siswa dan mendapatkan poinbegitu seterusnya hingga waktu yang ditentukan habis.

4) Setelah turnamen selesai maka dilakukan penilaiantiap anggota kelompok kembali kekelompoknya masing-masing kemudian menghitung perolehan poin yang didapat dari tiap anggota kelompok kemudian di akumulasikan.

5) Kelompok yang memperoleh poin tertinggi akan mendapat penghargaan berupa predikat great team, best team dan good team.

6) Pada pertemuan berikutnya guru melakukan bumping yaitu pergeseran tempat duduk pada saat turnamen. Anggota kelompok yang pada saat turnamen mendapat poin terbanyak akan naik tingkat. (Suyatno.2009:55-56)

\section{Kelemahan dan Kelebihan ModelPembelajaran TGT}

Riset tentang pengaruh pembelajaran kooperatif dalam pembelajaran telah banyak dilakukan oleh pakar pembelajaran maupun oleh para guru di sekolah. Dari tinjuan psikologis, terdapat dasar teoritis yang kuat untuk memprediksi bahwa metode-metode pembelajaran kooperatif yang menggunakan tujuan kelompok dan tanggung jawab individual akan meningkatkan pencapaian prestasi siswa. Dua teori utama yang mendukung pembelajaran kooperatif adalah teori motivasi dan teori kognitif.

Dari pespektif motivasional, struktur tujuan kooperatif menciptakan sebuah situasi di mana satu-satunya cara anggota kelompok bisa meraih tujuan pribadi mereka adalah jika kelompok mereka sukses. Oleh karena itu, mereka harus membantu teman satu timnya untuk melakukan apa pun agar kelompok berhasil dan mendorong anggota satu timnya untuk melakukan usaha maksimal.

Sedangkan dari perspektif teori kognitif, Slavin (2008) mengemukakan bahwa pembelajaran kooperatif menekankan pada pengaruh dari kerja sama terhadap pencapaian tujuan pembelajaran. Asumsi dasar dari teori pembangunan kognitif adalah bahwa interaksi di antara para siswa berkaitan dengan tugas-tugas yang sesuai mengingkatkan penguasaan mereka terhadap konsep kritik. Pengelompokan siswa yang heterogen mendorong interaksi yang kritis dan saling mendukung bagi pertumbuhan dan perkembangan pengetahuan atau kognitif. Penelitian psikologi kognitif menemukan bahwa jika informasi ingin dipertahankan di dalam memori dan berhubungan dengan informasi yang sudah ada di dalam memori, orang yang belajar harus terlibat dalam semacam pengaturan kembali kognitif, atau elaborasi dari materi. Salah satu cara elaborasi yang paling efektif adalah menjelaskan materinya kepada orang lain.

Namun demikian, tidak ada satupun model pembelajaran yang cocok untuk semua materi, situasi dan anak. Setiap model pembelajaran memiliki karakteristik yang menjadi penekanan dalam proses 
implementasinya dan sangat mendukung ketercapaian tujuan pembelajaran. Secara psikologis, lingkungan belajar yang diciptakan guru dapat direspon beragama oleh siswa sesuai dengan modalitas mereka. Dalam hal ini, pembelajaran kooperatif dengan teknik TGT, memiliki keunggulan dan kelemahan dalam implementasinya terutama dalam hal pencapaian hasil belajar dan efek psikologis bagi siswa.

Slavin (2010), melaporkan beberapa laporan hasil riset tentang pengaruh pembelajarankooperatif terhadap pencapaian belajar siswa yang secara inplisit mengemukakan keunggulan dan kelemahan pembelajaran TGT, sebagai berikut:

a. Para siswa di dalam kelas-kelas yang menggunakan TGT memperoleh teman yang secara signifikan lebih banyak dari kelompok rasial mereka dari pada siswa yang ada dalam kelas tradisional.

b. Meningkatkan perasaan/persepsi siswa bahwa hasil yang mereka peroleh tergantung dari kinerja dan bukannya pada keberuntungan.

c. TGT meningkatkan harga diri sosial pada siswa tetapi tidak untuk rasa harga diri akademik mereka.

d. TGT meningkatkan kekooperatifan terhadap yang lain (kerja sama verbal dan nonberbal, kompetisi yang lebih sedikit)

e. Keterlibatan siswa lebih tinggi dalam belajar bersama, tetapi menggunakan waktu yang lebih banyak.

f. TGT meningkatkan kehadiran siswa di sekolah pada remaja-remaja dengan gangguan emosional, lebih sedikit yang menerima skors atau perlakuan lain.

Sebuah catatan yang harus diperhatikan oleh guru dalam pembelajaran TGT adalah bahwa nilai kelompok tidaklah mencerminkan nilai individual siswa. Dengan demikian, guru harus merancang alat penilaian khusus untuk mengevaluasi tingkat pencapaian belajar siswa secara individual.

a. Kelebihan Pembelajaran TGT

Metode pembelajaran kooperatif Team Games Tournament (TGT) ini mempunyai kelebihan dan kekurangan. Menurut Suarjana (2000:10) dalam Istiqomah (2006), yang merupakan kelebihan dari pembelajaran TGT antara lain:

1) Lebih meningkatkan pencurahan waktu untuk tugas

2) Mengedepankan penerimaan terhadap perbedaan individu

3) Dengan waktu yang sedikit dapat menguasai materi secara mendalam

4) Proses belajar mengajar berlangsung dengan keaktifan dari siswa

5) Mendidik siswa untuk berlatih bersosialisasi dengan orang lain

6) Motivasi belajar lebih tinggi

7) Hasil belajar lebih baik

8) Meningkatkan kebaikan budi, kepekaan dan toleransi

b. Kelemahan TGT

1) Bagi Guru

Sulitnya pengelompokan siswa yang mempunyai kemampuan heterogen dari segi akademis. Kelemahan ini akan dapat diatasi jika guru yang bertindak sebagai pemegang kendali teliti dalam menentukan pembagian kelompok waktu yang dihabiskan untuk diskusi oleh siswa cukup banyak sehingga melewati waktu yang sudah ditetapkan. Kesulitan ini dapat diatasi jika guru mampu menguasai kelas secara menyeluruh.

2) Bagi Siswa

Masih adanya siswa berkemampuan tinggi kurang terbiasa dan sulit memberikan penjelasan kepada siswa lainnya. Untuk mengatasi kelemahan ini, tugas guru adalah membimbing dengan baik siswa yang mempunyai kemampuan akademik tinggi agar dapat dan mampu menularkan pengetahuannya kepada siswa yang lain.

\section{Pengertian Belajar}

Gagne dalam Suprijono (2011: 2), mengemukakan "belajar adalah perubahan disposisi atau kemampuan yang dicapai seseorang melalui aktivitas. Perubahan disposisi tersebut bukan diperoleh langsung dari proses pertumbuhan seseorang secara alamiah". Slavin (1994) dalam Rifa'i dan Anni (2009: 82), menyatakan "belajar 
merupakan perubahan individu yang disebabkan oleh pengalaman".

Slameto (2010: 2), mendefinisikan "belajar sebagai suatu proses usaha yang dilakukan individu untuk memperoleh perubahan tingkah laku secara keseluruhan sebagai hasil pengalaman individu dalam interaksi dengan lingkungannya".

Anthony Robbins, mendefinisikan belajar sebagai proses menciptakan hubungan antara sesuatu (pengetahuan) yang sudah dIPShami dan sesuatu(pengetahuan yang baru). Senada dengan Robbins, Jerime Brunner dalam Romberg \& Kaput (1999) mengemukakan bahwa belajar adalah suatu proses aktif di mana siswa membangun (mengkonstruk) pengetahuan baru berdasarkan pada pengalaman/pengetahuan yang sudah dimilikinya (Trianto 2009: 15).

Berdasarkan pengertian di atas maka dapat disimpulkan bahwa belajar merupakan proses perubahan tingkah laku individu sebagai akibat dari interaksi dengan lingkungan. Belajar bukan semata-mata mentransfer pengetahuan yang ada di luar dirinya, tetapi belajar lebih pada memproses dan menginterpretasikan pengalaman yang baru dengan pengetahuan yang sudah dimilikinya.

\section{Prinsip-prinsip Belajar}

Menurut Suprijono (2011: 4) ada tiga prinsip belajar, yaitu: (1) Belajar adalah perubahan tingkah laku; (2) Belajar merupakan proses; (3) Belajar merupakan bentuk pengalaman.

1) Belajar adalah perubahan tingkah laku

Perubahan tingkah laku sebagai hasil belajar memiliki ciri-ciri sebagai berikut: (a) Merupakan perubahan yang disadari, (b) kontinu atau berkesinambungan, (c) fungsional atau bermanfaat, (d) positif atau berakumulasi, (e) aktif atau sebagai usaha yang direncanakan, (f) permanen atau tetap, (g) bertujuan atau terarah, (h) mencakup keseluruhan potensi kemanusiaan.

2) Belajar merupakan proses

Belajar terjadi karena didorong kebutuhan dan tujuan yang ingin dicapai.
3) Belajar merupakan bentuk pengalaman

Pengalaman pada dasarnya adalah hasil dari interaksi antara siswa dengan lingkungannya.

Menurut Dimyati dan Mujiono (2008: 42-49) menyatakan bahwa ada tujuh prinsipprinsip belajar, yaitu: (1) perhatian dan motivasi, (2) keaktifan, (3) keterlibatan langsung/berpengalaman, (4) pengulangan, (5) tantangan, (6) balikan dan penguatan, (7) perbedaan individual. Sementara Anni dkk (2006: 36) menyatakan bahwa prinsipprinsip belajar meliputi penguatan (reinforcement), hukuman (punishment), kesegaran pemberian penguatan, jadwal pemberian penguatan, dan peranan stimulus terhadap perilaku.

Pengetahuan tentang teori dan prinsipprinsip belajar ini sangat membantu guru dalam memilih tindakan yang tepat pada saat pelaksanaan pembelajaran. Guru dapat memilih tindakan-tindakan yang dapat meningkatkan aktivitas dan hasil belajar siswa. Selain itu, guru juga dapat mengembangkan sikap yang menunjang peningkatan belajar

\section{Faktor-faktor yang Mempengaruhi Belajar}

Menurut Slameto (2010: 54-74), kegiatan belajar dipengaruhi oleh dua faktor, yaitu faktor intern dan faktor ekstern. Faktor intern adalah faktor yang ada dalam diri individu yang sedang belajar, sedangkan faktor ekstern adalah faktor yang ada di luar individu.

\section{Faktor intern}

Faktor intern meliputi jasmani terdiri dari kesehatan dan cacat tubuh, psikologis terdiri dari intelegensi, perhatian, minat, bakat, motif, kematangan, dan kesiapan dan kelelahan terdiri dari kelelahan jasmani dan rohani.

1) Jasmani terdiri dari kesehatan dan cacat tubuh. Agar seseorang dapat belajar dengan baik maka ia harus menjaga kesehatan badannya. Keadaan cacat tubuh juga dapat mempengaruhi belajar. 
2) Psikologis terdiri dari intelegensi, perhatian, minat, bakat, motif, kematangan, dan kesiapan. Intelegensi atau kecakapan yang dimiliki seseorang dapat mempengaruhi belajar. Begitu pula dengan perhatian dan minat, jika siswa tidak memiliki perhatian dan minat pada bahan pelajaran, ia bisa merasa bosan dan tidak suka terhadap apa yang dipelajarinya.

3) Kelelahan terdiri dari kelelahan jasmani dan rohani. Keduanya dapat mempengaruhi belajar. Agar siswa dapat belajar dengan baik haruslah menghindari kelelahan.

\section{Faktor ekstern}

Faktor ekstern adalah faktor yang ada di luar individu. Faktor ekstern yang dapat berpengaruh terhadap belajar, yaitu:

1) Keluarga, siswa yang belajar akan menerima pengaruh dari keluarga berupa cara orang tua mendidik, relasi antara anggota keluarga, suasana rumah tangga, keadaan ekonomi rumah tangga, pengertian orang tua, dan latar belakang kebudayaan.

2) Sekolah, faktor sekolah yang mempengaruhi kegiatan belajar mencakup metode mengajar, kurikulum, relasi guru dengan siswa, disiplin sekolah, pelajaran dan waktu sekolah, standar pelajaran, keadaan gedung, metode belajar dan tugas rumah.

3) Masyarakat merupakan faktor ekstern yang berpengaruh terhadap belajar siswa. Pengaruh itu terjadi karena keberadaan siswa dalam masyarakat.

Adapun hal yang mempengaruhi siswa dalam masyarakat yaitu kegiatan siswa, mass media, teman bergaul, dan bentuk kehidupan masyarakat.

\section{Aktivitas Belajar Siswa}

Menurut Poerwadarminta (2003) dalam Yusfy (2011), "aktivitas adalah kegiatan. Jadi aktivitas belajar adalah kegiatan-kegiatan siswa yang menunjang keberhasilan belajar". Sedangkan menurut Slameto (2010: 36), mengemukakan bahwa "aktivitas belajar merupakan kegiatan siswa dalam berpikir dan berbuat, berupa kegiatan bertanya, mengajukan pendapat, dan menimbulkan diskusi dengan guru".

Dalam hal kegiatan belajar, Rosseuau dalam Yusfy (2011), memberikan penjelasan bahwa segala pengetahuan itu harus diperoleh dengan pengamatan sendiri, penyelidikan sendiri, dengan bekerja sendiri baik secara rohani maupun teknis. Tanpa ada aktivitas, proses belajar tidak mungkin terjadi. Aktivitas belajar yang dimaksud adalah seluruh aktivitas siswa dalam proses belajar, mulai dari kegiatan fisik sampai kegiatan psikis. Kemudian Sardiman (2007) dalam Yusfy (2011), menegaskan bahwa "pada prinsipnya belajar adalah berbuat, tidak ada belajar jika tidak ada aktivitas. Itulah mengapa aktivitas merupakan prinsip yang sangat penting dalam interaksi belajar mengajar".

Berdasarkan pengertian di atas, dapat disimpulkan bahwa aktivitas belajar siswa adalah suatu proses kegiatan belajar yang berupa interaksi antara guru dengan siswa yang menimbulkan perubahan kemampuan atau kecakapan siswa.

Berikut adalah aktifitas siswa yang dinilai dalam penelitian ini, yaitu: (1) kesiapan siswa mengikuti pembelajaran, (2) keaktifan siswa ketika menerima penjelasan tentang tujuan belajar, (3) keaktifan siswa dalam kegiatan eksplorasi, (4) keaktifan siswa dalam kegiatan elaborasi 1 (kelompok asal), (5) keaktifan siswa dalam kegiatan elaborasi 2 (kelompok ahli), (6) keberanian siswa dalam mempresentasikan hasil diskusi, (7) keaktifan siswa dalam kegiatan konfirmasi, (8) keaktifan siswa dalam kegiatan akhir pembelajaran.

\section{Hasil Belajar Siswa}

Menurut Woordworth dalam Farhan (2011), "hasil belajar merupakan perubahan tingkah laku sebagai akibat dari proses belajar". Sementara Anni dkk (2006: 5) mengemukakan bahwa "hasil belajar merupakan perubahan perilaku yang diperoleh pembelajar setelah mengalami aktivitas belajar". 
Menurut Bloom dalam Rifa'i dan Anni (2009: 86), menyatakan bahwa "hasil belajar meliputi tiga taksonomi yang disebut dengan ranah belajar, yaitu ranah kognitif (cognitive domain), ranah sikap (affective domain), dan ranah psikomotorik (psychomotoric domain)".

Berdasarkan pengertian di atas, dapat disimpulkan bahwa hasil belajar siswa pada hakikatnya merupakan perubahan tingkah laku setelah melalui proses belajar mengajar. Tingkah laku sebagai hasil belajar dalam pengertian luas mencakup bidang kognitif, afektif dan psikomotorik. Penilaian dan pengukuran hasil belajar dilakukan dengan menggunakan tes hasil belajar, terutama hasil belajar kognitif berkenaan dengan penguasaan bahan pengajaran sesuai dengan tujuan pendidikan dan pengajaran.

Berikut adalah hasil belajar yang dimaksud dalam penelitian ini yaitu peningkatan nilai yang diperoleh siswa setelah dilakukan tes formatif. Pembelajaran dikatakan berhasil jika terjadi peningkatan hasil belajar yaitu pencapaian hasil belajar siswa sudah memenuhi KKM yang ditetapkan. Selain itu, juga adanya perubahan perilaku positif yang dialami siswa setelah proses pembelajaran.

\section{METODOLOGI PENELITIAN Waktu dan Tempat Penelitian}

Penelitian ini dilaksanakan mulai tanggal 14 Februari sd 22 Juni 2016 yang dilaksanakan di SMP Negeri 1 Bandar Baru Kecamatan Bandar Baru Kabupaten Pidie Jaya.

\section{Rancangan penelitian.}

Prosedur penelitian tindakan kelas diawali dengan perencanaan tindakan (planning), penerapan tindakan (action), mengobservasi (observation), dan refleksi (reflecting) dan seterusnya sampai kriteria keberhasilan yang diharapkan tercapai. Penelitian ini direncanakan minimal dalam dua siklus, yaitu tindakan pada siklus I sampai dengan tercapainya tujuan perbaikan dengan batas akhir sesuai waktu yang dialokasikan kurikulum. Proses tindakan yang dilakukan dalam penelitian tindakan kelas ini dapat dilihat pada gambar berikut:

Tahapan alur penelitian tindakan kelas digambarkan oleh Arikunto (2009: 16) berikut:

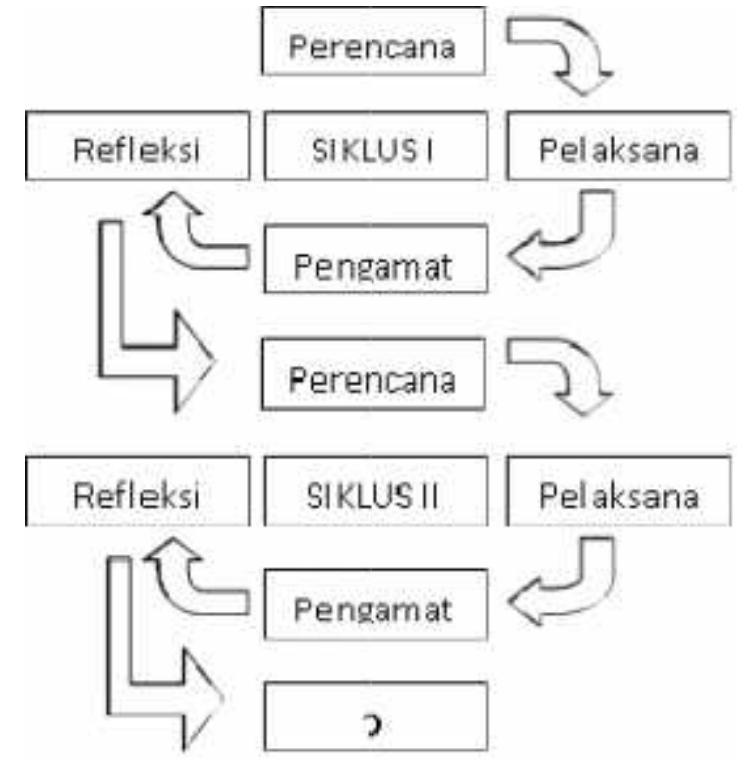

\section{Perencanaan}

"Perencanaan merupakan tahap berupa menyusun rancangan tindakan yang menjelaskan apa, mengapa, kapan, dimana, oleh siapa dan bagaimana tindakan tersebut akan dilakukan" (Arikunto 2009: 75). Pada tahap perencanaan, peneliti mengidentifikasi masalah yang terjadi di kelas terlebih dahulu. Kemudian menyusun lembar pengamatan aktivitas belajar siswa dan performansi guru pada Pelaksanaansaat proses belajar mengajar berlangsung. Setelah itu membuat Rencana Pelaksanaan Pembelajaran (RPP), merancang media dan tes formatif.

\section{Pelaksanaan tindakan}

"Pelaksanaan tindakan merupakan implementasi atau penerapan isi rancangan, yaitu mengenai tindakan kelas" (Arikunto 2009:18). Pada tahap pelaksanaan, peneliti melakukan kegiatan pembelajaran sesuai rencana pembelajaran yang telah dibuat. Kegiatan pembelajaran tersebut dimulai dengan kegiatan awal yaitu menyampaikan apersepsi. Setelah apersepsi kemudian dilanjutkan dengan kegiatan inti yaitu proses belajar mengajar dengan menggunakan model TGT (Team Game Tournament). Terakhir, kegiatan penutup untuk mengetahui sejauh mana pemahaman siswa terhadap materi yang telah disampaikan.

\section{Observasi}


"Observasi adalah kegiatan pengamatan yang dilakukan oleh pengamat" (Arikunto 2009:19). Observasi bertujuan untuk mengamati kegiatan penelitian yang telah direncanakan. Observasi dilakukan secara kolaborasi antara peneliti dan rekan peneliti. Peneliti akan mengobservasi proses pembelajaran dengan siswa dan rekan peneliti akan mengobservasi aktivitas siswa serta performansi peneliti saat kegiatan pembelajaran.

\section{Refleksi}

"Refleksi merupakan kegiatan untuk mengemukakan kembali apa yang sudah dilakukan" (Arikunto 2009:19). Refleksi merupakan langkah untuk menganalisis semua kegiatan yang telah dilakukan. Analisis dilakukan untuk mengetahui kelebihan dan kekurangan unsur-unsur yang diamati. Apabila ada kekurangan maka peneliti merefleksikan hasil analisis tersebut untuk merencanakan tindakan selanjutnya menuju perbaikan.

\section{Perencanaan Tahap Penelitian}

Penelitian tindakan kelas dilaksanakan minimal dalam dua siklus. Siklus terdiri dari 2 pertemuan, siklus II terdiri dari 2 pertemuan. Setiap siklus dilaksanakan melalui 4 tahap yaitu: perencanaan (planning), tindakan (action), mengobservasi (observation), dan refleksi (reflecting).

\section{Teknik Pengumpulan Data}

Teknik pengumpulan data yang digunakan dalam penelitian ini yaitu teknik tes dan teknik nontes.

\section{Teknik tes}

"Tes adalah himpunan pertanyaan yang harus dijawab, pertanyaan-pertanyan yang harus dipilih atau ditanggapi, atau tugas-tugas yang harus dilakukan peserta tes dengan tujuan mengukur suatu aspek tertentu" (Poerwanti 2008:4-3). Dalam penelitian ini terdapat dua macam tes yang dilaksanakan, yaitu tes awal (tes awal) dan tes formatif. Tes awal digunakan untuk mengetahui kemampuan awal siswa terhadap konsep yang akan diajarkan dan dilaksanakan sebelum kegiatan belajar mengajar berlangsung sedangkan tes formatif digunakan untuk memperoleh data hasil belajar Bahasa Inggris selama menggunakan model TGT (Team Game Tournament).

\section{Teknik nontes}

Teknik non tes digunakan 2 macam teknik, yaitu:

1 Observasi

"Observasi adalah kegiatan pengamatan untuk memotret seberapa jauh efek tindakan telah mencapai sasaran" (Arikunto 2009: 127). Teknik observasi digunakan untuk menggambarkan aktivitas siswa dan guru dalam pembelajaran Bahasa Inggris dengan menggunakan model TGT (Team Game Tournament). Observasi dilakukan oleh observer dalam hal ini guru kelas $\mathrm{V}$ dan rekan peneliti dengan menggunakan lembar pengamatan. Adapun lembar pengamatan yang digunakan adalah lembar pengamatan aktivitas siswa, lembar pengamatan aktivitas guru .

2 Dokumentasi

Menurut Paul (2011), "dokumentasi adalah kegiatan khusus berupa pengumpulan, pengolahan, penyimpanan, penemuan kembali dan penyebaran dokumen". Dokumentasi yang dilakukan oleh peneliti adalah untuk mengumpulkan data tentang: nama siswa, nomor induk siswa, dan hasil belajar yang diperoleh siswa sebelum dan sesudah pembelajaran Bahasa Inggris dengan menggunakan model TGT (Team Game Tournament). Selain itu, dokumentasi dilakukan untuk memperkuat data yang diperoleh observer mengenai kegiatan kelompok siswa, suasana kelas ketika berlangsungnya proses pembelajaran dengan menggunakan dokumen berupa foto.

\section{HASIL PENELITIAN DAN PEMBAHASAN}

Pembelajaran sebelum pelaksanaan tindakan kelas guru mengajar secara konvensional. Guru cenderung mentransper ilmu kepada siswa, sehingga siswa hanya 
mendengar dan siswa kurang aktif bahkan cenderung bosan. Proses pembelajaran tampak kaku karena siswa hanya melihat dan mendengar apa yang dijelaskan gurunya. Itu semua berdampak pada hasil nilai siswa di Kelas VIII.5 SMP Negeri 1 Bandar Baru.

Tabel 1. Perolehan Data Hasil Belajar Sebelum Diberikan Tindakan

\begin{tabular}{|l|c|c|}
\hline \multirow{2}{*}{ Prestasi Belajar } & \multicolumn{2}{|c|}{$\begin{array}{c}\text { Hasil Tes Pra Siklus (Skor } \\
\text { Dasar) }\end{array}$} \\
\cline { 2 - 3 } & $\begin{array}{l}\text { Banyak } \\
\text { Siswa }\end{array}$ & Persentase (\%) \\
\hline $\begin{array}{l}\text { Jumlah siswa } \\
\text { tuntas belajar } \\
\text { (skor } \geq 70)\end{array}$ & 7 & $33 \%$ \\
\hline $\begin{array}{l}\text { Jumlah siswa } \\
\text { tidak tuntas } \\
\text { belajar (skor } \leq \\
\text { 69) }\end{array}$ & 14 & $67 \%$ \\
\hline Rata-rata kelas & \multicolumn{2}{|c|}{$\mathbf{6 0 , 7 1}$} \\
\hline
\end{tabular}

\section{Deskripsi Data Pelaksanaan Tindakan siklus I}

Tindakan siklus I dilaksanakan tanggal 15 Februari 2016. Data yang diperoleh selama pelaksanaan tindakan siklus I, yaitu data hasil belajar dan data hasil observasi selama proses pembelajaran. Berikut akan dibahas paparan dari kedua data tersebut.

Tabel 2 Data Hasil Belajar Siklus I

\begin{tabular}{|l|c|c|}
\hline \multirow{2}{*}{ Prestasi Belajar } & \multicolumn{2}{|c|}{$\begin{array}{c}\text { Hasil Tes Siklus I (Skor } \\
\text { Dasar) }\end{array}$} \\
\cline { 2 - 3 } & $\begin{array}{l}\text { Banyak } \\
\text { Siswa }\end{array}$ & $\begin{array}{c}\text { Persentase } \\
(\%)\end{array}$ \\
\hline $\begin{array}{l}\text { Jumlah siswa } \\
\text { tuntas belajar } \\
\text { (skor } \geq 70)\end{array}$ & 10 & $48 \%$ \\
\hline $\begin{array}{l}\text { Jumlah siswa } \\
\text { tidak tuntas } \\
\text { belajar (skor } \leq\end{array}$ & & \\
70) & 11 & $52 \%$ \\
\hline Rata-rata kelas & \multicolumn{2}{|c|}{$\mathbf{6 8 , 1 0}$} \\
\hline
\end{tabular}

\section{Deskripsi Observasi Proses Pembelajaran}

Peneliti mengamati siswa pada waktu pembelajaran. Apakah dengan menerapkan metode Team Game Tournament (TGT) dapat membantu siswa untuk memahami konsep. Berdasarkan observasi menunjukkan bahwa dengan metode Team Game Tournament (TGT) siswa lebih tertarik dan senang mengikuti kegiatan pembelajaran Bahasa Inggris, meskipun masih terlihat ada beberapa siswa yang kurang antusias. Guru membimbing siswa, mengadakan evaluasi dan mengolah data yang diperoleh, mengidentifikasi dan menginterpretasi data untuk menentukan tingkat pencapaian tindakan.

\section{Hasil Observasi Kinerja Guru}

Pengamatan terhadap kemampuan guru dalam pengelolaan pembelajaran pada siklus I diperoleh nilai akhir kemampuan guru dalam pengelolaan pembelajaran sebesar 30 atau rata-rata 3,00 yang termasuk dalam kriteria Baik. Untuk lebih jelas dapat di lihat tabel berikut ini :

Tabel 3. Observasi Keterampilan Guru Siklus I

\begin{tabular}{|c|c|c|}
\hline No & Indikator & Siklus I \\
\hline 1 & $\begin{array}{ll}\text { Membuka } & \text { pelajaran } \\
\text { (keterampilan } & \text { membuka } \\
\text { pelajaran) } & \\
\end{array}$ & 4 \\
\hline 2 & $\begin{array}{l}\text { Memberikanpenguatan } \\
\text { (keterampilanmemberi } \\
\text { penguatan) }\end{array}$ & 3 \\
\hline 3 & $\begin{array}{lr}\text { Melakukan } & \text { konstruktivisme } \\
\text { pengetahuan kepada siswa } \\
\text { (keterampilan menjelaskan, } \\
\text { keterampilan membimbing } \\
\begin{array}{l}\text { diskusi } \\
\text { (konstruktivisme) }\end{array} \\
\end{array}$ & 2 \\
\hline 4 & $\begin{array}{lr}\text { Membimbing } & \text { siswa } \\
\text { melakukan } & \text { kegiatan } \\
\text { menemukan } & \text { pengetahuannya } \\
\text { sendiri } & \text { (keterampilan } \\
\text { membimbing } & \text { diskusi } \\
\text { kelompok kecil) (inkuiri) }\end{array}$ & 4 \\
\hline 5 & $\begin{array}{l}\text { Bertanya (keterampilan } \\
\text { bertanya) (bertanya) }\end{array}$ & 3 \\
\hline 6 & $\begin{array}{l}\text { Pengadaan masyarakat belajar } \\
\text { (keterampilan membimbing } \\
\text { diskusi kelompok kecil) } \\
\text { (masyarakat belajar) }\end{array}$ & 3 \\
\hline 7 & $\begin{array}{lr}\text { Membimbing } & \text { siswa } \\
\text { mempersentasikan } & \text { hasil } \\
\text { diskusi } & \text { (keterampilan }\end{array}$ & 3 \\
\hline
\end{tabular}




\begin{tabular}{|c|c|c|}
\hline & $\begin{array}{l}\text { menjelaskan dan keterampilan } \\
\text { mengadakan } \\
\text { (pemodelan) }\end{array}$ & \\
\hline 8 & $\begin{array}{l}\text { Membimbing siswa menarik } \\
\text { kesimpulan dan melakukan } \\
\text { refleksi } \text { (keterampilan } \\
\text { membimbing r diskusi } \\
\text { kelompok kecil, keterampilan } \\
\text { menjelaskan, keterampilan } \\
\text { pembelajaran perseorangan ) } \\
\text { (refleksi) }\end{array}$ & 3 \\
\hline 9 & $\begin{array}{l}\text { Penilaian } \\
\text { (keterampilan mengelola } \\
\text { kelas) (penilaian autentik) }\end{array}$ & 2 \\
\hline 10 & $\begin{array}{ll}\text { Menutup } & \text { pelajaran } \\
\text { (keterampilan } & \text { menutup } \\
\text { pelajaraan) } & \end{array}$ & 3 \\
\hline \multicolumn{2}{|c|}{ Jumlah } & 30 \\
\hline \multicolumn{2}{|c|}{ Rata-Rata } & 3,00 \\
\hline \multicolumn{2}{|c|}{ Kategori } & Baik \\
\hline
\end{tabular}

Tabel 4 HasilObservasi Aktivitas Siswa Siklus I

\begin{tabular}{|c|l|c|c|}
\hline No & $\begin{array}{l}\text { Indikator Aktivitas } \\
\text { Siswa }\end{array}$ & $\begin{array}{c}\text { Jumla } \\
\text { h total } \\
\text { skor }\end{array}$ & $\begin{array}{c}\text { Rata- } \\
\text { rata } \\
\text { Skor }\end{array}$ \\
\hline 1 & $\begin{array}{l}\text { Kesiapan belajar } \\
\text { siswa }\end{array}$ & 48 & 2.29 \\
\hline 2 & $\begin{array}{l}\text { Keterlibatan siswa } \\
\text { dalam pembelajaran }\end{array}$ & 44 & 2.10 \\
\hline 3 & $\begin{array}{l}\text { Kemampuan } \\
\text { menjawab pertanyaan } \\
\text { guru }\end{array}$ & 49 & 2.33 \\
\hline 4 & $\begin{array}{l}\text { Kemampuan } \\
\text { menyampaikan } \\
\text { pendapat }\end{array}$ & 46 & 2.19 \\
\hline 5 & $\begin{array}{l}\text { Kemampuan bertanya } \\
\text { pada guru }\end{array}$ & 43 & 2.05 \\
\hline 6 & $\begin{array}{l}\text { Kemampuan } \\
\text { mempresentasikan } \\
\text { hasil diskusi } \\
\text { kelompok }\end{array}$ & 46 & 2.19 \\
\hline 7 & $\begin{array}{l}\text { Melakukan kegiatan } \\
\text { refleksi }\end{array}$ & 45 & 2.14 \\
\hline 8 & $\begin{array}{l}\text { Kemampuan } \\
\text { mengerjakan soal } \\
\text { evaluasi }\end{array}$ & \multicolumn{2}{|c|}{$\mathbf{3 6 3}$} \\
\hline $\begin{array}{l}\text { Jumlah Skor yang } \\
\text { diperoleh }\end{array}$ & \multicolumn{2}{|c|}{ Cukup } \\
\hline Rata-rata skor total & \multicolumn{2}{|c|}{} \\
\hline Kategori & \multicolumn{2}{|c|}{} \\
\hline
\end{tabular}

Deskripsi Data Pelaksanaan Tindakan SiklusII
Data hasil pelaksanaan tindakan siklus I seperti yang dipaparkan di atas, menunjukkan bahwa hasil pembelajaran dengan menerapkan model Team Game Tournament (TGT) masih kurang memuaskan. Untuk itu peneliti melaksanakan tindakan lanjutan, yaitu berupa pelaksanaan tindakan siklus II guna memperbaiki hasil pembelajaran pada siklus I. Tindakan Siklus II dilaksanakan pada tanggal 12 dan 16 Maret 2016.

\section{Paparan Hasil Belajar}

Setelah dilakukan pelaksanaan tindakan pembelajaran siklus I diperoleh data hasil belajar siswa yang dapat dilihat pada tabel berikut ini :

Tabel 5 Data Haisl Belajar Siklus II

\begin{tabular}{|l|c|c|}
\hline \multirow{2}{*}{ Prestasi Belajar } & \multicolumn{2}{|c|}{$\begin{array}{c}\text { Hasil Tes Siklus I } \\
\text { (Skor Dasar) }\end{array}$} \\
\cline { 2 - 3 } & $\begin{array}{c}\text { Banyak } \\
\text { Siswa }\end{array}$ & $\begin{array}{c}\text { Persentase } \\
(\%)\end{array}$ \\
\hline $\begin{array}{l}\text { Jumlah siswa tuntas } \\
\text { belajar (skor } \geq 70)\end{array}$ & 20 & $95 \%$ \\
\hline $\begin{array}{l}\text { Jumlah siswa tidak } \\
\text { tuntas belajar (skor } \\
\leq 69 \text { ) }\end{array}$ & 1 & $5 \%$ \\
\hline Rata-rata kelas & \multicolumn{2}{|c|}{$\mathbf{8 0 , 0 0}$} \\
\hline
\end{tabular}

\section{Deskripsi Observasi Proses Pembelajaran}

Peneliti mengamati siswa pada waktu pembelajaran. Apakah dengan melakukan penerapan metode Team Game Tournament (TGT) dapat membantu siswa untuk memahami konsep manusia. Berdasarkan observasi setelah guru memodifikasi metode Team Game Tournament (TGT) dalam praktek Bahasa Inggris dengan penyampaian materi menunjukkan bahwa siswa lebih tertarik, senang dan antusias mengikuti kegiatan pembelajaran Bahasa Inggris. Guru membimbing siswa, mengadakan evaluasi dan mengolah data yang diperoleh, mengidentifikasi dan menginterpretasi data untuk menentukan tingkat pencapaian tindakan. 


\section{Hasil Observasi Kinerja Guru}

Pengamatan terhadap kemampuan guru dalam pengelolaan pembelajaran pada siklus I diperoleh nilai akhir kemampuan guru dalam pengelolaan pembelajaran sebesar 37 atau 3,70 yang termasuk dalam kriteria sangat baik. Untuk lebih jelas dapat di lihat tabel berikut ini :

Tabel 6 Observasi Keterampilan Guru Siklus II

\begin{tabular}{|c|c|c|}
\hline No & Indikator & Siklus II \\
\hline 1 & $\begin{array}{l}\text { Membuka pelajaran } \\
\text { (keterampilan } \\
\text { membuka pelajaran) }\end{array}$ & 4 \\
\hline 2 & $\begin{array}{l}\text { Memberikan penguatan } \\
\text { (keterampilanmemberi } \\
\text { penguatan) }\end{array}$ & 4 \\
\hline 3 & $\begin{array}{l}\text { Melakukan } \\
\text { konstruktivisme } \\
\text { pengetahuan kepada } \\
\text { siswa (keterampilan } \\
\text { menjelaskan, } \\
\text { keterampilan } \\
\text { membimbing diskusi } \\
\text { kecil) (konstruktivisme) }\end{array}$ & 3 \\
\hline 4 & $\begin{array}{lr}\text { Membimbing } & \text { siswa } \\
\text { melakukan } & \text { kegiatan } \\
\text { menemukan } & \\
\text { pengetahuannya } & \text { sendiri } \\
\text { (keterampilan } & \\
\text { membimbing } & \text { diskusi } \\
\text { kelompok } & \text { kecil) } \\
\text { (inkuiri) } & \\
\end{array}$ & 4 \\
\hline 5 & $\begin{array}{l}\text { Bertanya (keterampilan } \\
\text { bertanya) (bertanya) }\end{array}$ & 4 \\
\hline 6 & $\begin{array}{l}\text { Pengadaan masyarakat } \\
\text { belajar (keterampilan } \\
\text { membimbing diskusi } \\
\text { kelompok kecil) } \\
\text { (masyarakat belajar) }\end{array}$ & 3 \\
\hline 7 & $\begin{array}{l}\text { Membimbing siswa } \\
\text { mempersentasikan hasil } \\
\text { diskusi (keterampilan } \\
\text { menjelaskan dan } \\
\text { keterampilan } \\
\text { mengadakan variasi) } \\
\text { (pemodelan) }\end{array}$ & 4 \\
\hline 8 & $\begin{array}{l}\text { Membimbing siswa } \\
\text { menarik kesimpulan } \\
\text { dan melakukan refleksi } \\
\text { (keterampilan }\end{array}$ & 4 \\
\hline
\end{tabular}

\begin{tabular}{|c|l|c|}
\hline & $\begin{array}{l}\text { membimbing diskusi } \\
\text { kelompok } \\
\text { keterampilan } \\
\text { menjelaskan, } \\
\text { keterampilan } \\
\text { pembelajaran } \\
\text { perseorangan } \\
\text { (refleksi) }\end{array}$ \\
\hline 9 & $\begin{array}{l}\text { Penilaian autentik } \\
\text { (keterampilan } \\
\text { mengelola kras) } \\
\text { (penilaian autentik) }\end{array}$ & 3 \\
\hline 10 & $\begin{array}{l}\text { Menutup pelajaran } \\
\text { (keterampilan menutup } \\
\text { pelajaraan) }\end{array}$ & 4 \\
\hline Jumlah & $\mathbf{3 7}$ \\
\hline Rata-Rata & Sangat Baik \\
\hline Kategori
\end{tabular}

\section{Hasil Observasi Aktivitas Siswa}

Pengamatan aktivitas siswa pada siklus II diperoleh hasil di atas skor total nilai aktivitas siswa dalam pembelajaran sebesar 25,74, yang termasuk dalam kriteria baik

Tabel 7 Hasil Observasi Aktivitas Siswa Siklus II

\begin{tabular}{|c|l|c|c|}
\hline No & \multicolumn{1}{|c|}{$\begin{array}{c}\text { Indikator } \\
\text { Aktivitas Siswa }\end{array}$} & $\begin{array}{c}\text { Jumla } \\
\text { h total } \\
\text { skor }\end{array}$ & $\begin{array}{c}\text { Rata- } \\
\text { rata } \\
\text { Skor }\end{array}$ \\
\hline 1 & $\begin{array}{l}\text { Kesiapan belajar } \\
\text { siswa }\end{array}$ & 67 & 3.19 \\
\hline 2 & $\begin{array}{l}\text { Keterlibatan siswa } \\
\text { dalam } \\
\text { pembelajaran }\end{array}$ & 66 & 3.14 \\
\hline 3 & $\begin{array}{l}\text { Kemampuan } \\
\text { menjawab } \\
\text { pertanyaan guru }\end{array}$ & 61 & 2.90 \\
\hline 4 & $\begin{array}{l}\text { Kemampuan } \\
\text { menyampaikan } \\
\text { pendapat }\end{array}$ & 67 & 3.19 \\
\hline 5 & $\begin{array}{l}\text { Kemampuan } \\
\text { bertanya pada guru }\end{array}$ & 68 & 3.24 \\
\hline 6 & $\begin{array}{l}\text { Kemampuan } \\
\text { mempresentasikan } \\
\text { hasil diskusi } \\
\text { kelompok }\end{array}$ & 68 & 3.24 \\
\hline 7 & $\begin{array}{l}\text { Melakukan } \\
\text { kegiatan refleksi }\end{array}$ & 64 & 3.05 \\
\hline 8 & $\begin{array}{l}\text { Kemampuan } \\
\text { mengerjakan soal }\end{array}$ & 67 & 3.19 \\
\hline
\end{tabular}




\begin{tabular}{|l|c|}
\hline \multicolumn{1}{|c|}{ evaluasi } & \\
\hline $\begin{array}{l}\text { Jumlah Skor yang } \\
\text { diperoleh }\end{array}$ & $\mathbf{5 2 8}$ \\
\hline Rata-rata skor total & $\mathbf{2 5 . 1 4}$ \\
\hline Kategori & Baik \\
\hline
\end{tabular}

Berdasarkan hasil penelitian dapat ditarik beberapa kesimpulan penting sebagai jawaban atas masalah-masalah penelitian yang telah dikemukakan di awal penelitian/tulisan, sebagai berikut:

1. Penerapan metode TGT (Teams Game Tournament) terbukti bisa meningkatkan hasil belajar siswa Kelas VIII.5 SMP Negeri 1 Bandar Baru Tahun Pelajaran terhadap materi pokok pembelajaran "Unit self-test" pada Bidang Studi Bahasa Inggris. Peningkatannya sangat signifikan, dari $48 \%$ pada siklus pertama menjadi $95 \%$ pada siklus kedua, yang berarti prestasi belajar dan aktivitas belajar siswa lainnya mengalami kenaikan sebesar $47 \%$.

2. Penerapan metode TGT (Teams Game Tournament) terbukti juga bisa meningkatkan kualitas pembelajaran Bahasa Inggris dan ketuntasan belajar siswa Kelas VIII.5I SMP Negeri 1 Bandar Baru Tahun Pelajaran 2015/2016 terhadap materi pokok pembelajaran “ Unit self-test" pada Bidang Studi Bahasa Inggris, suatu peningkatan yang boleh dibilang sangat luar biasa signifikan, dari $48 \%$ yang belum tuntas pada siklus pertama menjadi $4 \%$ pada siklus kedua. Itu artinya, penerapan metode TGT (Teams Game Tournament) sampai akhir siklus kedua terbukti berhasil menuntaskan pembelajaran $95 \%$ dari 21 siswa subyek penelit

\section{Daftar Pustaka}

Arikunto, S. dkk. 2008. Penelitian Tindakan Kelas. Jakarta: Bumi Aksara.

Asma, N. 2006. Model Pembelajaran Kooperatif. Jakarta: Depdiknas Dikti.
Dimyati dan Mujiono. 2008. Belajar dan Pembelajaran. Jakarta : Dineka Cipta.

Emildadiany, N. 2008. Cooperative Learning Teknik TGT (Team Game Tournament). Online http://akhmadsudrajat.wordpress.co $\mathrm{m} / 2008 / 07 / 31 /$ cooperativelearningteknik- TGT (Team Game Tournament)/ [diakses 28/12/15]

Hadis, A. dan Nuryahati. 2010. Manajemen Mutu Pendidikan. Bandung: Alfabeta.

Isjoni. 2010. Cooperatif Learning. Bandung: Alfabeta.

Kurnia, I. 2007. Perkembangan Belajar Peserta Didik. Jakarta: DIRJEN DIKTI DEPDIKNAS.

Munib, A. dkk. 2009. Pengantar Ilmu Pendidikan. Semarang: UPT MKK UNNES.

Paul. 2011. Pengertian Dokumentasi. Online http://wawanjunaidi. blogspot.com/2011/12/pengertiandokumentasi.html [diakses 10/12/2015].

Poerwanti, E. dkk. 2008. Asessmen Pembelajaran. Jakarta: Direktorat Jenderal Pendidikan Tinggi Depdiknas.

Slameto. 2010. Belajar dan Faktor-Faktor yang Mempengaruhi. Jakarta: Rineka Cipta.

Suprijono, A. 2011. Cooperative Learning: Teori dan Aplikasi PAIKEM. Yogyakarta: Pustaka Pelajar. 